\title{
Character Building Through Sport, Physical and Health Education to Realize Golden Generation
}

\author{
( Survey to Students of Vocational Secondary Schools in East Pontianak Sub-district)
}

\author{
Victor Simanjuntak \\ Study Program of Sports, Health, and Recreation Education, \\ Department of Sports Science, Faculty of Teacher Training and Education, \\ Tanjungpura University \\ Pontianak, Indonesia \\ victorgsim@yahoo.co.id
}

\begin{abstract}
The present study was designed to investigate the role of sport, physical and health education as a character building of students to realize the golden generation. This study applied a descriptive and quantitative approach with a survey method. The data were collected with proportional sampling numbering of 80 participants out of the total population $(527$ students) from SMK Negeri 7, SMK Cinta Bumi Khatulistiwa, and SMK Mandiri Kecamatan Pontianak Timur. The study results were dominantly categorized very good.
\end{abstract}

Keywords-Character, Sports Physical and Health Education.

\section{INTRODUCTION}

The National Education System Act [1] defines education as conscious and planned attempts to realize learning atmospheres and teaching processes to enable the students to develop their own potentials actively to have religious and spiritual power, self-control, personality, intellectuality, good characters, and skills required by themselves, the community, the nation, and the country.

The national education is aimed at educating people and developing Indonesians those are religious and believing in One God, having good characters, knowledge and skills, physical and mental health, good and independent personality, as well as performing responsibility for the community and the nation [2].

One of the subjects taught in the high schools is physical, sport and health education (hereafter called penjasorkes). This is a learning activity designed to improve physical fitness through movement activities. Ref. [3] claims that penjasorkes is typically a process of education functioning physical activities to produce holistic changes of individual quality physically, mentally, and emotionally.

In this respect, penjasorkes is one of important development aspects in the national character building for Indonesians. Penjasorkes teaches discipline, builds up spirits of sportiveness, toughness, competitiveness, cooperation, and rule-consciousness. In addition, it teaches the students to make a decision and to have work spirits covering loyalty, pride, as well as honor. In short, penjasorkes will build up healthy personality if it is used properly in line with its portion and it will be able to help the students grow their characters.
Character education is used as the foundation to materialize the vision of the national development, that is, to actualize the community having good and proper morals, etiquettes, culture and behaviours based on the national philosophy of Pancasila. Besides, various problems recently faced by the nation push the government to prioritize the character education as the basis of education development. The building up of characters in line with the national culture should be implemented in schools not only through series of teaching and learning activities, but also through habituation in their religious, fair, discipline, tolerant, collaborative, peace-loving, and responsible daily life. Therefore, penjasorkes plays significantly as a habituating center through cognitive, affective, and psychomotoric teaching-learning processes.

The social reality in Pontianak shows decreasing trend in characters, morals, and etiquettes among students. It may due to the education in the community, in the families, and in the schools, those have not run well. There are weaknesses in term of education among the community, the families, and the schools. For instance, the subjects taught in schools are more theoretical and cognitive aspects rather than affective and psychomotoric aspects. The intellectual-based approach must be balanced with morals and personality-based approach in order the students develop their social behaviours acceptable by the present norms and priciples practised in the community.

Social disorders [4] can be in the forms of mischievous behaviours, criminal acts, unlawful behaviours, juvenile delinquency, inter-school fighting, unmaried pregnancy, sexual harrasment, vehicles stealing, prostitution, gambling, drinking, and drug abuse.

Inter-school fighting is now getting serious. The student fighters bring cold steel and bedevil the opponents. Therefore, the opponents can have serious injuries and even they can be killed [5].

Students of vocational secondary schools in East Pontianak Sub-disctrict is the generation that are prepared to be better and more reliable generation and more ready for work in the field. For this reason, their thoughts and characters must be designed, protected, and paid special attention. Unfortunately, it is not easy because it is influenced by negative practices and by irresponsible parties. 
Referring to the above grounds, a question about how big the role of penjaorkes in building the students' characters. The objective of this study is to investigate the role of penjaorkes in building the characters of vocational secondary school students in East Pontianak Sub-district to realize the golden generation.

\section{LITERATURE REVIEW}

\section{A. Physical Sport and Health Education}

Reference [6] claims that "penjasorkes" is a part of an educational process as a whole. Physical sport education is defined as a systematic process of various activities or attempts that can support, arouse, develop, and build one's physical and mental potentials as an individual or a member of a group in a game, competition, and physical activity intensively to get a recreation, winning an ultimate achievement in the attempt to build Pancasila-characterized Indonesians [7].

Penjasorkes is a process of educating one as an individual and a member of a community that is run consciously through various physical activities to improve skills, growth, wits, and characters [8]. The objectives of physical education are building strong characters through value internalization in physical education; building up personality foundation that is strong, peace-loving, social attitudes, tolerance in the settings of multicultural, multiethnicity, and multi-divine beliefs; developing critical thinking through assignments of physical education process; and development that is sportive, fair, discipline, responsible, collaborative, self-confident, and democratic through physical activities [9].

Then, penjasorkes is an arena to educate students as the young generation in the future who may be effective to reach the educational objectives; to teach various values of education, personality development covering fairness, discipline, selfconfidence, and responsibility. In this concern, character building through penjasorkes teaching includes building physics that is healthy, fit, strong, excellent, and competitive; building mentality that is supportive, democratic, tolerant, and discipline; building morals that are sensitive, fair, and sincere; and building social competence covering able to compete, to be a friend, and to be a good citizen [7].

Penjasorkes teaching indirectly builds the positive characters of the students. The teaching of this subject includes positive values. If the teaching is successful, the values can be applied in their daily life. Besides having their body fit, through the penjaskorkes subject the students will be attributed to positive characters. Thus, this subject can be taught compulsorily in educational institutions.

The above concept shows that students are taught not only the cognitive aspect but also the values that support the humanity. The perception of the ideal Indonesians mentioned above cannot be actualized perfectly. However, this ideal perception should be used as the basic guide to reach the defined education objectives.

\section{B. Character}

Character covers three elements. They are knowing the good, loving the good, and doing the good [10]. Classify a character into weak character, strong character, and bad character. People with weak character can be identified as not risk-takers, lazy, and easy to lose. People with a strong character are identified as hard to defeat, tough having strong fighting spirit. Bad character includes shifty, selfish, greedy, arrogant, uppish, snobbish, and show off. Good characters cover honest, reliable, lowly, and trustable [11].

Reference [12] refers character education to a process of internalizing the primary attributes that become the specific characteristics of the society into the hearts of the students. Therefore, they can grow and develop into adult humans with the cultural values of the relevant community. According to [13], character education is a process of guiding the students to become complete humans who have characters in dimensions of heart, thought, idea, body, feeling, and intention.

Will penjasorkes be able to educate students in term of how to show democratic behaviour, good character, discipline in obeying the prevailing rules and laws? How can penjasorkes help students control their behaviours? Reference [14] introduces character values - religious: obedient to the rules of their religion, tolerant to other religion practices, living peacefully with other religion followers; honest: trustable in their words, actions, and works; tolerant: respect the practices of different religions, tribes, and ethnic groups; discipline: order in behaviours and obedient to rules and regulations; friendly/ communicative: maintaining pleasing and interactive communication and cooperation with other people; hard work: showing serious attempts to overcome various constraints in learning and doing tasks; peace-loving: making other people pleased and secured with the speech and behaviours; creative: thinking and doing something to produce new ways or results of what they possess; fond of reading: accustomed to allocating time to read various texts that develop themselves; environment-conscious: always showing attitudes and actions preventing damages in their natural environment and developing attitudes and actions to repair the natural environment damages; curious: having attitudes and actions to know deeper and wider the things that they learn, observe, and listen; responsible: doing some action for themselves and their environment.

Therefore, penjasorkes can play a role in building and developing characters of the students to actualize the golden generation who are smart comprehensively, intellectually, emotionally, socially, spiritually, and physically [15].

\section{METHOD}

The present study applied a descriptive-qualitative approach. The method was a survey. The population was students of vocational secondary schools throughout East Pontianak Sub-district; a total of 527 students. They consisted of 353 students from SMK Negeri 7, 48 students from SMK Cinta Bumi Khatulistiwa, and 126 students from SMK Mandiri. The samples were 80 students taken with sampling proportional technique [16].

The data were collected by questionnaires. Each item contained moral values scaled by Likert completed with alternative models of 5 options. They are SL = always, $\mathrm{SR}=$ often, $\mathrm{KD}=$ sometimes, $\mathrm{P}=$ once, and $\mathrm{TP}=$ never. Validity and 
reliability of were measured with Bivariate Pearson using SPSS 16. The total questionnaires numbered 45 items, and there were only 36 items considered significantly valid and reliable and used as a tool of data collection.

\section{RESULT AND DiSCUSSION}

\section{A. Result}

The study result is presented in the following table and graph.

TABle 1: STUdENTS' CharaCter BUILDING CATEGORY OF VOCATIONAL SECONDARY SCHOOLS THROUGHOUT EAST PONTIANAK SUB-DISTRICT

\begin{tabular}{|c|c|c|}
\hline Category & Score & Persentage \\
\hline Very Good & 1349 & 46.89 \\
\hline Good & 600 & 20.85 \\
\hline Moderate & 643 & 22.35 \\
\hline Poor & 204 & 7.09 \\
\hline Very Poor & 81 & 2.82 \\
\hline Total & 2877 & 100 \\
\hline
\end{tabular}

As can be seen in Tabel 1, students' characters can be built through penjasorkes. They can be classified into five categories: very good with the score of 1349 (46.89\%), good $600(20.85 \%)$, moderate $643(22.35 \%)$, poor $204(7.09 \%)$, and very poor $81(2.82 \%)$. The average score of very good and good to show good character is $67.74 \%$ and the character score of $22.35 \%$ is to show moderate character.

\section{B. Discussion}

Referring to the above data analysis, out of 80 samples the character building through penjasorkes can be classified into very good $46.89 \%$ (38 students), and good $20.85 \%$ (17 students). It indicates that most students have shown good characters. There are only 18 students (22.35\%) whose characters are moderate.

There are only 5 students $(7.09 \%)$ with poor character and 2 students $(2.82 \%)$ with very poor character. Thus, it is important especially for the teachers of penjasorkes, the teachers of other subjects, and the headmaster, to pay more attention to build the students with good characters.

Reference [17] claims that the character development is the result of an integrated process of long life formal and informal education. Classify the primary education objectives intended by the educators and the public into academic competence development and character development. They do not stand by themselves, but they complete each other [18].

The result of this study also shows that 3 of 12 characters score that became the focus of the observation are the love of peace, fond of reading, and curiosity. The score for the category very good and good is smaller than that categorized moderate. The score of the 9 characters: religious, honest and so forth is bigger for good and very good than that for moderate.

To find out the solution to social problems can be implemented through the role of the schools, the families, and the community particularly that have a significant influence on character building [18].

\section{CONCLUSION AND SugGESTIONS}

\section{A. Conclusion}

Character building through penjasorkes makes most students have good characters, and some others have moderate characters. There are only a few students who need guidance.

\section{B. Suggestions}

Referring to the above conclusion, the following suggestions will be proposed: (1) schools should improve the role of the subject matters, particularly penjasorkes because teaching-learning process during this subject contains character building to actualize the golden generation., (2) that the character building is an interesting field that needs deeper study with more samples.

\section{REFERENCES}

[1] A. N. Cahyo, Guide of Applying Teaching and Learning Theories. Jakarta: Diva Press, 2013, p.18

[2] Soedijarto, National Education as a medium to Educate the Nation and to Develop the National Civilization, Jakarta: CINAPS, 2000.

[3] HJS. Husdarta, Physical Education Management. Bandung: Alfabeta, 2011, p.3

[4] G. Nurmantyo, Understanding Threats and Realizing One's Identity as a Capital to Develop Golden Indonesian Era. Jakarta: Military Headquarter of Indonesia, 2016, p. 34

[5] Koran Sindo, Student Gang Fighting. Tuesday 14 March 2017. Jakarta: Sindo Press, 2017

[6] R. Lutan, Principles of Physical Education. Jakarta: Directorate General for Sports. National Education Ministry, 2001, p.2

[7] T. K. Mutohir, et al., Having Characters through Sports, Doing Sports with Characters and Sports Developing National Characters. Surabaya: PT Java Pustaka Group. 2011.

[8] Directorate General for Sports, Community Sports Development in Indonesia. Jakarta. National Education Ministry, 2004, p.15

[9] Samsudin, Curriculum of Sport, Physical and Health Education. Jakarta: Postgraduate Program of State University of Jakarta, 2012, p. 33

[10] A. Majid and A. Dian, Character Education from Islamic Perspective. Bandung: Remaja Rosdakarya, 2011, p. 11

[11] H. L. Elfindri, et al., Character Education: Methods and Application for Professional Educators. Jakarta: Baduose Media, 2012, pp. 27-28

[12] B. Mustakim, Character Education: Developing Eight Golden Characters for Prestigious Indonesia. Yogyakarta: Samudra Biru, 2011, p. 28

[13] M. Samani, and Hariyanto. Character Education. Bandung: PT Remaja Rosdakarya, 2012, p. 45

[14] R. Listyarti, Chacater Education in Active, Innovative, Creative Method. Jakarta: Erlangga, 2012, p. 5-8

[15] J. H. Matsum, "Developing National Characters to Materialize Golden Generation," Seminar Attended by Teachers from Sambas Regency from 8 to 9 September 2016. Pontianak: Tanjungpura University, 2016, p.6

[16] H. Usman, and P. R. S. Akbar, Introduction to Statistics. Jakarta: PT. Bumi Aksara, 2009, p. 185

[17] S.K. Stoll and J.M. Beller, Do Sports Build Characters? In J.r. Gerdy, Sport in School: The future of an Instruction. New York: Teaching College Press, 2000, p. 27

[18] Dimyati, "Differences of Youth Characters Viewed from Participations in Sports Activities and Type of Sport". National Sports Seminar on 26 May 2007. Bali: Publication Unit of Undiksha Singaraja, 2007, p.208 